\title{
Arte, crítica e liberdade
}

Art, criticism and freedom

Flávio R. Kothe

Professor titular de Estética na FAU/UnB, autor de obras sobre o cânone brasileiro, teoria literária e a arte comparada, tradutor de Nietzsche, Marx, Kafka, Benjamin, Adorno e outros, autor de poemas, contos e novelas.

frkothe@unb.br

\section{Resumo}

Pressupostos teológicos marcaram a Estética e a Teoria do Conhecimento nos séculos XVII e XVIII e continuam marcando o modo de entender a arte e a realidade em teorias do século XIX e XX. O retorno às origens da Estética moderna propicia a exposição das estruturas fundantes, sem o que vai se continuar só fazendo variações em torno do mesmo.

Palavras-chaves: Estética. Teologia. Desconstrução. Descartes. Wolff. Baumgarten. Kant.

\section{Abstract}

Theological presuppositions have marked Aesthetics and Epistemology during XVII and XVIII centuries and they continue to mark the way of understanding art and reality in theories on the XIX and XX centuries. The return to the origins of modern Aesthetics inducts the exposition of fundamental structures, without which we will just do variations on the same.

Keywords: Aesthetics. Theology. Deconstruction. Descartes. Wolff. Baumgarten. Kant. 


\section{Teologia da Estética}

A Estética deriva de uma crença que pode conter um erro grave, nos fundamentos, e toda sua edificação pode afundar. Oriunda da metafísica psicológica, ela pressupõe que o homem se divida em corpo e alma, como instâncias separáveis, tendo a alma prioridade por ser imutável, eterna e independente do corpo. Assim como a Lógica cuidaria das ilações da alma em termos analíticos, a Estética cuidaria das percepções corporais, das imagens corpóreas. Essa concepção cristã está presente em Descartes, Leibniz, Wolff, Baumgarten, Kant, Fichte, Solger, Hegel e vários outros. Ela não é propriamente anterior ao cristianismo: os romanos, por exemplo, acreditavam que "a sombra" ia para os Campos Elísios, mas esses não ficavam num "Além" fora da "physis".

Havia na escolástica uma "lógica superior”, analítica, voltada para o pensamento abstrato, mantendo um controle sobre como ele deveria ser. No século XVIII, com Wolff e Baumgarten, foi proposta a contrapartida do estudo da "Lógica inferior", a "Estética" voltada para as regiões ínferas, consideradas corpóreas, pois aí também ocorreriam processos de conhecimento, basicamente mediante imagens fugidias. A "Estética" de Baumgarten ${ }^{1}$ ( $§ 1$ ) juntava áreas diversas: gnoseologia inferior, teoria das artes liberais, a arte das cogitações belas, arte do análogo da razão: seria a ciência dos conhecimentos sensitivos.

Às vezes ela recebe a variante de que o homem não seria constituído por duas partes e sim por três: corpo, alma e espírito. No signo verbal, o corpo está para o significante assim como o significado está para a alma, mas quando se usa uma ironia o sentido da palavra tende a ser o contrário do significado usual. Há, portanto, uma terceira instância, o espírito da obra. Na Crítica da razão pura, por exemplo, a dimensão corpórea está no que ela chamava de Estética - que não era uma Filosofia da Arte - ou seja, a região das percepções dos sentidos; a alma está no entendimento conceitual, uma espécie de Espírito Santo que há no homem, enquanto o espírito está no nível mais elevado da Razão, que tudo comanda com suas três ideias: Deus, imortalidade, liberdade: o tico, o teco e o toco.

O problema central é discernir o cerne teológico que habita a filosofia e a estética, fazendo dos pensadores antes teólogos disfarçados do que propriamente filósofos, caso se aceite a proposta de Heidegger - que ele próprio não cumpriu plenamente - de que a filosofia é ateia por natureza. Numa era de recrudescimento do fanatismo religioso, esse problema se torna mais premente. O monoteísmo religioso tende a levar ao totalitarismo, pois quem só admite um único deus verdadeiro, o seu, não tem tolerância quanto à elevação de outras divindades. A saída não é a regressão ao politeísmo antigo, mas se desvencilhar das religiões: "sem deuses mais".

A distinção entre corpo e alma parecia fácil: corpo seria uma coisa com extensão, sendo, portanto, divisível; em contrapartida, a alma seria o indivisível. Embora Descartes tenha adotado isso em suas obras principais, nas Paixões da alma ${ }^{2}$ observou que a alma também se divide: tem uma parte em que ela sente as coisas; outra que entende as coisas e ainda uma que decide sobre as coisas. No século XVII e XVIII não se tinha noção clara de que haveria o inconsciente, embora Shakespeare tenha percebido isso. Para nós, desde a psicanálise é natural que "a alma" se divida em consciente, pré-consciente e inconsciente. Quando se dividem as coisas, deveria chegar um momento em que elas não se poderiam dividir mais: é o ponto matemático, cruzamento de duas linhas, que "é sem estar aí”, é um "não-ser que é" e que funda tudo (ou afunda tudo no nada). Tudo o que há se baseia num "não estar" que "é".

Numa situação de guerra, sob canhoneio, um soldado se apavora, fica pálido e quer se esconder, enquanto outro fica furioso, vermelho de raiva e se dispõe a enfrentar o fogo do inimigo de peito aberto. Para a mesma causa deveria haver as mesmas consequências, e isso não ocorre. Se suas "almas" têm a mesma origem divina, por que reagem de modo oposto? Cada "alma" capta os dados do real, discerne a situação, provoca uma reação somática e uma ação volitiva. Sofrer os dados equivale à figura de Cristo, que corporifica o sofrimento; a intelecção dos dados é feita pelo entendimento, que corresponde ao Espírito Santo, enquanto a expressão divina da vontade é Deus Pai, que decide fazer e desfazer as coisas. Há, porém, além dessa Santíssima Trindade, uma quarta figura, aquela que faz com que o espírito somatize reações corpóreas e que corresponde à figura da Virgem Maria, aquela que fez o espírito se tornar carne e habitar entre humanos.

\section{Arquitetura do pensamento}

Quando os filósofos do século XVIII se puseram a desenvolver a "metafísica psicológica", estavam fazendo algo sacrílego, ou seja, tentar decifrar o que seria a "alma" posta por Deus no homem, mas transpuseram as categorias teológicas para o âmbito 
da teoria do conhecimento. Eles procuravam a "arquitetura da mente" e tinham um plano "arquitetônico" em seus sistemas. Isso fica mais claro no "robô" construído por Kant na Crítica da razão pura. Ele tem sensores - os sentidos - que captam imagens dos fenômenos das coisas e que as levam ao "entendimento" (Verstand), que as organiza conforme os conceitos - é a programação de que ele é dotado, o que leva a decisões conforme os princípios volitivos da razão (Vernunft) mediada pelo juízo.

Se em Descartes, nas Paixões da alma, paira a sugestão de que a "alma" se divide em três (eu diria quatro) partes - a intelecção sendo o equivalente ao Espírito Santo, o sentimento ao Cristo e a vontade ao Deus Pai, pode-se acrescentar a somatização dos movimentos psíquicos como equivalente à Virgem Maria, aquela que fez o espírito se tornar carne - essas mesmas categorias teológicas católicas se encontram em Kant, embora este tivesse um background antes luterano do que católico. O "esquema" (no sentido mesmo de esquematismo da razão) da Crítica da razão pura pode ser visto na forma de uma pirâmide, em que a parte de baixo é formada pela multiplicidade caótica das percepções, o corpo, a "estética transcendental"; a parte intermediária pelo sistema conceptual do entendimento (Verstand); e a parte superior pela razão, com suas três ideias de Deus, liberdade e imortalidade.

Ou seja, o que comanda tudo é a razão, vista como transposição da figura de Deus Pai; o entendimento que é a intelecção das coisas seria a transposição do Espírito Santo, enquanto que aquele que carrega o que se sente, o estético, seria o equivalente a Cristo. Depois de apresentar esse tríptico, Kant se lembra de colocar entre a segunda e a terceira instância a faculdade do juízo, que fica transpondo as ordens da razão para as atividades concretas, ou seja, é a Virgem Maria que reaparece, aquela que faz o espírito se tornar carne e decisão concreta, a mediação do divino com o humano. Kant usa explicitamente o termo "arquitetura" para designar a estrutura da mente.

Se for tomada uma casa como modelo, pode-se supor também que os fundamentos são os dados fornecidos pelos sensores que são os sentidos, os fornecedores de matéria prima, o Cristo sobre o qual se funda toda a fé cristã; a parte das salas e dos quartos é ocupada pela vida da mente, pela programação conceptual, ou seja, o Espírito Santo; o teto é a formatação do juízo, ou seja, corresponde à Virgem Maria, aquela que torna concreta, torna carne, o que seria a vontade puramente espiritual do que representa o divino, enquanto o telhado que tudo cobre é a razão, que representa a vontade do Deus Pai. Ou seja, deus não é apenas uma ideia da razão, a ser distinguida da crença em deus (e assim representaria o início e o fim de todas as coisas, portanto esconderia atrás de si a astronomia e a astrofísica): o divino cristão - em suas quatro divindades católicas básicas - serve para estruturar a própria mente. A mente que pudesse ser considerada humana só poderia ser, então, a mentalidade cristã, a que é feita em conformidade com a estrutura da crença europeia dominante.

Marx usou essa imagem de uma edificação para entender a relação entre cultura, sociedade e modo de produção. Este seria a base, o alicerce, sobre o qual se construiria a estrutura social, que seria como os quartos e salas da moradia, enquanto o telhado formaria a supraestrutura cultural. O termo que ele usa é “Bau”, uma construção, uma edificação, uma casa, o que se perdeu quando se traduziu isso por estrutura, que é antes o esqueleto da construção. Daí os termos "Unterbau" para os alicerces econômicos e "Ueberbau" para a expressão (Ausdruck) cultural deles.

Temos de olhar de fora essa construção em que habitamos, que nos é. Fácil é aí comparar as pessoas e dizer que umas parecem choupanas, outras taperas decadentes, outras construções populares, há uma classe média de construção e mansões de classe alta, assim como há palácios ideativos. A construção é, porém, algo rígido, uma casa não de morar, mas de pensar. Como ficam, porém, a liberdade e a inventividade dentro disso? Seriam a movimentação de quem aí habita, dentro do previsível? Constroemse fundamentos, paredes, tetos e telhados para gerar vazios. Tudo o que se faz é aí feito para gerar um nãoser. Ele não é, porém, idêntico ao grande feito na ciência ou na arte que produz algo não igual ao já previsto. Ou seja, aquilo que mais distingue o homem não tem espaço na metáfora da edificação.

\section{Imaginação}

Pascal $^{3}$ assegura que acima de tudo ele preza a honestidade, mas tem um pensamento curto que diz "poète, et non honnête homme". Noutro momento varia o provérbio latino "in vino veritas", dizendo que é preciso não haver vinho demais nem vinho de menos para buscar a verdade. Será que Pascal, saindo da ciência e se tornando monge católico, era tão honesto a ponto de julgar todos os poetas como sendo desonestos? Não estava ele acreditando na ficção do "milagre
3

Pascal. Pensées. Paris, GarnierFlammarion, 1976. A tradução às vezes é própria, outras vezes segue a de Sérgio Melliet publicada em 1979, na Coleção Pensadores, da Editora Abril de São Paulo. 
do espinho de Port Royal" e nas ficções produzidas por poetas romanos sobre a história de Cristo?

Embora Descartes tenha questionado a correção de muitas percepções sensoriais, Pascal é quem mais radicalmente questionou a validade da imaginação. Comparado com ele, Wolff, Baumgarten, Gerard e Kant são ingênuos em sua visão otimista quanto ao papel dela no conhecimento. Que Pascal exclua o poeta do âmbito das pessoas honestas ("honnêtes hommes" foi traduzido, na Edição da Abril, por "homens de bem", o que talvez não seja a mesma coisa, pois estes tendem a ser confundidos com "homens de bens", que é exatamente o que ele está questionando), pode levar a duvidar da honestidade dos homens honestos, mas aponta nos poetas sujeitos enganadores, que dão às palavras sentidos pouco habituais e inventam coisas que não existem.

Fernando Pessoa fez uma variação em torno disso, dizendo que "o poeta é um fingidor que finge que é dor a dor que deveras sente", o que aponta para a elaboração do sofrimento (como poderia ser também da alegria) no texto a partir de uma dor real, efetiva. Seria uma mímese como nova produção por imitação, à qual se objetaria não ser o original. Ora, uma obra se torna mais significativa à medida que modifica a coisa, ampliando sua expressividade. Mesmo no sonho, as mudanças nas cenas rememoradas são feitas em função de forças reprimidas que querem alcançar expressão.

Essa dor que deveras se sente é mimetizada, como ponto de partida, mas transmutada de tal maneira que, no ôntico casual, se capta o ontológico, o mais abrangente, seu caráter simbólico, significativo para outros. Costuma-se dizer que a teoria mimética provém de Aristóteles, pois efetivamente ele, na Poética, diz que o homem é um animal imitador. Mais que o homem, camaleão e polvo são imitadores também. Isso por si não gera arte. 0 que a gera é a diferença introduzida, a "deformação significativa”. A imitação já está, porém, na criação bíblica do homem, que se diz ter sido feito à imagem e semelhança de Jeová" (um absurdo lógico, já que as características do homem são antitéticas às de Deus). O primeiro mandamento da lei mosaica proíbe qualquer forma de imitação, mas em seguida, quando os judeus são picados por serpentes no deserto (??), Jeová manda fazer a imagem de uma serpente dizendo que todos picados seriam curados (Deus tudo pode, até fazer arte salvacionista).
Na mesma obra, Aristóteles tem a passagem de que a poesia seria mais universal do que a história, já que esta contém episódios singulares, enquanto a poesia seria mais "universal", por contar o que poderia ter acontecido. Isso está mal formulado nas duas direções. Os episódios históricos não são contados como contas isoladas de um rosário, mas dentro de uma sequência que pretende ser significativa, pois pretende ver algo mais amplo que cada um deles, como a formação de um país, a expansão e decadência de um império. 0 que se propõe na poesia conjuga o singular e o universal no particular de modo típico e significativo.

“O que poderia ter acontecido" leva ao princípio da verossimilhança, que é fundamental em Baumgarten. Subjacente está o conceito de verdade como identidade, seja do que está no real em relação a um mundo das ideias, seja a realidade se refletindo na mente como num espelho. $\mathrm{O}$ "semelhante a" busca uma identidade e se mensura por ela, como se supõe que a "verdade" é adequação entre a coisa e o que está na mente, ou seja, um ad-aequum, ao mesmo. Isso se expressa na matemática pelo $X=Y$. Ele nunca é, porém, o igual, já porque a imagem que está na mente não é a própria coisa, já porque a igualdade matemática é um "arredondamento", um fingir que é exatamente igual o que é apenas semelhante, desconsiderandose a diferença.

Dois mil anos de cristianismo impregnaram nas mentes a noção de que há um ente que é O Ser, Deus. Aristóteles já havia observado, no entanto, que nenhum ente pode ser o ser, pois ele é um ente determinado, não um ente que possa ser todos e tudo. Com esse O Ser, colocou-se a transcendência em um além, separado dos homens, acima de tudo, para dar poder a uma casta religiosa que se propunha e se impõe como sendo a única conexão entre esses dois mundos: ela tem o cadeado, a chave e a porta da salvação. Temos de abandonar essa porta. Ela não leva a nada, é o nada, o "me engana que eu gosto". Ao propor que esse Ser Supremo seria a unidade de tudo, sugere que o ser está em tudo porque tudo é produto de sua criação a partir do nada. Ele é, portanto, paradoxal: por um lado, separado de tudo; por outro, em tudo, sendo tudo.

Platão, na "República"4 (Politeia - não propõe propriamente uma forma republicana de governo e sim por castas de filósofos) propõe duas alternativas para a questão de como coisas que tenham alguma identidade passam a ter um determinado nome que as designa: ou se teria um modelo, um protótipo no mundo das ideias, que seria copiado nas coisas, ou 
então se ter a fabulação de um nome pelo reflexo das coisas na mente, como se esta fosse um grande espelho. Assim se inventou uma contraposição entre idealismo e materialismo, que imperou por vinte e cinco séculos, em que os adeptos do primeiro se achavam melhores que os do segundo. Hoje se trata de superar os dois, questionando seu ponto de partida lógico.

Seja a realidade uma cópia do mundo das ideias, seja o mundo das ideias um reflexo de uma realidade préexistente, o que se tem é uma "equivalência" entre dois mundos, uma duplicação em que um deve "valer tanto quanto" o outro, ou ao menos ser sua cópia fidedigna. Quando se dá prioridade ao mundo prévio das ideias, todas as cópias são inferiores aos protótipos. Quando se priorizam as coisas reais, todo conceptual se torna algo imaginário, uma fabulação que pode ou não ser.

De um ou de outro modo, a verdade seria a adequação (ad aequum), uma identidade entre as duas instâncias. Isso se expressa na matemática com uma equação em que $\mathrm{X}=\mathrm{Y}$. Tanto nas academias gregas havia no pórtico a vedação de entrar quem não entendesse de matemática, quanto no pensamento moderno, com Descartes, Leibniz, Wolffe Kant, o modelo geométrico matemático foi proposto como "ideias claras e distintas", tendo a chancela de Deus, que impediria que, mesmo o sujeito dormindo, $2+3$ não poderia deixar de ser $=5$ e um triângulo não deixaria de ser uma figura geométrica com somente três ângulos. Não se mudou propriamente o modelo de pensamento.

O que não se tinha entre os gregos, talvez exceto os pitagóricos, era a crença em um Deus todo poderoso a garantir números e geometrias. Como ele foi feito? O cristianismo diz que ele é Jeová transmutado, no que não acreditam nem judeus nem muçulmanos, pois este não mandou um anjo cantar uma moça, não fez um filho, não foi derrubado do poder pelo filho, que teria se entronizado no lugar dele. O problema é a transcendência.

Aristóteles diz claramente que nenhum ente pode ser o ser. Cada ente é o que ele é por ele se transcender em outros entes, por semelhança ou contraste. Em todo ente já está contida uma dimensão ontológica, que não está num outro mundo, noutra dimensão, mas nas próprias coisas. Nos termos de Hegel, aquilo que faz de um cavalo ser um cavalo, sua cavalidade, está contida em todos os cavalos, por mais diferentes que sejam. A sua essência é simultânea à sua existência, não anterior, como no mundo das ideias, nem posterior, como no espelho. O que se coloca na mente humana é algo que já está presente nas coisas, desde que a apreensão seja verdadeira.

O que o cristianismo fez foi a duplicação metafísica do mundo, inventou um ente que seria o ser dos seres, Deus. Só que um ente tão determinado quanto ele, não pode ser "o ser" de todos os entes. Ele é uma impossibilidade lógica. Se ele fosse infinito, teria de ser todas as coisas que existem e, portanto, se confundiria com elas. Quando Aristóteles falou em "theos", era para designar aquilo que estaria além do horizonte da nossa apreensão e compreensão das coisas, portanto era algo que fazia parte do cosmos, era intramúndico, assim como os deuses eram parte da "physis". Os cristãos se tornaram prisioneiros de sua própria imaginação. Até hoje, quando supomos algo como o inconsciente, ele assume dimensões de um "outro mundo" contido no sujeito, mas ele não pode ser tão diferente deste, já que faz parte dele.

\section{Adequação}

O conceito de verdade tem se baseado na identidade entre a coisa e o que dela está na mente, seja lá como uma parte vai copiar a outra. A questão mimética não envolve apenas a criação artística ou o processo de uma pessoa imitar outra, mas envolve todo o processo cognitivo e, quando se inventou que o homem é feito à imagem e semelhança de Deus, se tornou um problema da natureza do ser humano, querendo-se que fosse a sua cópia mal feita, na verdade antes uma caricatura, uma antítese do que uma reprodução. É preciso rever a noção de verdade, a partir da suspensão da duplicação imaginária do mundo.

No platonismo, adotado por Agostinho e tornado doutrina católica, o "mundo das ideias", transposto para a mente divina, seria um lar dos protótipos: o que era especulação filosófica, uma hipótese refutada na mesma obra de Platão, se tornou crença e dogma, princípio de explicação do homem, do universo e do processo de conhecimento. $O$ que o homem conhece teria de refletir algo da perfeição divina e, portanto, a lei "científica" teria de ser universal e necessária, a refletir a onisciência e onipotência de Deus. Até hoje estamos dominados por isso, não só na população crédula, mas também na universidade, em que as ciências ditas exatas se pretendem superiores, mais sérias e exatas, do que as artes e as ditas ciências humanas. A exatidão das "ciências exatas" se baseia na matemática, que não é tão exata, seja porque reduz o real ao numérico, 
seja porque ela reduz o parecido ao igual, menosprezando a diferença como se ela não existisse.

No platonismo cristão (platonismo para os pobres, segundo Nietzsche, tanto para os pobres materiais, dando a todos o consolo de uma alma eterna, seja para os pobres de espírito), as ideias estão armazenadas na "mente divina" (e a partir dela tomam corpo: "faça-se a luz, e a luz se fez"), elas seriam a realidade última de tudo, sendo as coisas reais meras cópias provisórias, que poderiam ser todas substituídas quando desse na veneta desse Deus que precisa exigir amor dos homens para se sentir bem, como se amor se exigisse. Que Deus diga "faça-se a luz" faz derivar tudo da palavra, a verdade como sediada no discurso. Por extensão, estáse reconhecendo que a Bíblia é obra verbal, produto da imaginação criativa. Para poder dizer algo, esse Jeová precisaria ter um corpo antropomórfico. E um secretário, que anotasse o que ele dizia.

Platão não era platônico. Ele diz, através de Sócrates, que não existe o mundo das ideias, que ele é apenas um reflexo das coisas na mente do homem, como um espelho. O problema é que nessa versão ainda se mantém uma duplicação implícita: o real e aquilo que está na mente humana, na cultura. Perde-se aí um passo fundamental, que é o de reconhecer a relação ontológica em todo o ôntico. A mente humana não acrescenta simplesmente o ontológico, como se os entes fossem todos indivíduos singulares, que nada tivessem a ver uns com os outros. A relação com outros já está em cada um. Cada ente se transcende: não há transcendência divina porque a transcendência é imanente a todas as coisas.

O modelo da razão ocidental é a ratio matemática, que se baseia numa regra de proporcionalidade: 2 está para 3 assim como 4 para 6 , ou então $2 \times 6=3$ $x$ 4. Parece lógico, racional, preciso: assim é que se precisa pensar, dizia-se. Está dentro de uma lógica analítica, numérica. A arte é que sempre esteve aí para atrapalhar essa pretensão das ideias claras e distintas, nela sempre esteve presente o obscuro, o contraditório, o confuso. Ela fazia da obscuridade profissão de fé. Quando parecia muito clara, era propaganda.

Em Descartes ou Wolffé insistente a assertiva de que um triângulo tem de ter 3 ângulos, ele não pode ter 4 , 5 ou 6 (que vamos ter se não contarmos apenas os ângulos internos da figura). Um quadrado deve ter 4 lados: mas se eu contar o lado de dentro e o de fora, terei 2; se somar os lados de dentro com os de fora, terei 8. Ele pode ser, portanto, uma figura com 2, 4, 5,
6, 7 ou 8 lados. Wolff no máximo examina a possibilidade de um triângulo ter 3 ângulos iguais (isósceles) ou ter um ângulo reto (mas não poderia ter dois) ou que uma forma quadrangular não tenha todos os ângulos em 90 graus. Na literatura, um triângulo amoroso é, porém, algo bastante movimentado, sendo a forma triangular apenas uma abstração, que não corresponde à dinâmica das relações.

Descartes, em seu ensaio sobre Geometria, começou a mostrar como as questões geométricas e matemáticas podem se tornar complicadas, difíceis de entender para quem não for especialista ${ }^{5}$. Com isso, ele estava colocando em questão o modelo pelo qual responde, de ideias claras e distintas como critério de verdade. O que parece evidente a uns não é tão evidente a outros, ou ao menos tolera outros tipos de resposta. 0 modelo de ideias claras e distintas não é a matemática e sim o catecismo.

Se o modelo abscôndito das "noções claras e distintas" era o catecismo, sabe-se hoje que neste há respostas simples e claras para perguntas sobre existência, origem das coisas, origem do homem, constituição do ser humano, destino da vida ou do universo e assim por diante. Que noções sejam claras e distintas não garante, porém, que elas sejam verdadeiras; que milhões de pessoas estejam convictas durante muitos séculos de sua validade, não lhes garante veracidade. São uma questão de crença, e a crença é uma suspensão da dúvida, da reflexão: é a imposição do dogma.

O catecismo desvia das questões principais, sendo a primeira delas por que tantas pessoas acreditam nas teses sem comprovação que ele prega. A resposta principal é o medo da morte, a inconformidade com a própria finitude. Tem-se um cadáver num velório e o padre ou pastor se acham no direito de dizer que o defunto está na vida eterna, da qual não existe nenhuma comprovação. Nessa situação ninguém vai questionar o que é dito, está-se numa cerimônia de passagem, numa despedida, com respeito aos familiares e amigos. Todos se sentem ameaçados pela presença da morte: ela lhes basta para acreditarem no exato oposto, e rezam alto para exorcizar o destino inevitável de todo ser vivo, não só dos humanos. 0 fervor de sua crença não faz com que exista realmente uma vida eterna, um mundo além, um deus que a todos protege e ama e salva.

A crença na fabulação a torna concreta para as pessoas, nesse sentido ela é real, mas não passa de uma fantasmagoria, uma invenção, um produto da 
"facultas fingendi". Os crentes se consideram superiores aos "ateus", como se eles tivessem deus só porque acreditam nele, como se viessem a ter uma vida eterna por acreditarem nela. Como não vão ter nada disso, não sentirão a perda porque estarão mortos. Possuem menos pensando ter mais. Não são honestos com os fatos, embora suponham ser melhores que os "ateus", definidos por uma ausência, uma perda. "Ideias claras e distintas" não são "ideias" no sentido hegeliano de algo verdadeiro: elas parecem claras e distintas, mas fica aí obscuro por que se acredita em algo que não é evidente, que não é claro nem distinto.

Descartes escondeu sob a aparência do modelo geométrico-matemático o modelo oriundo do catecismo. Ele não podia discutir o catecismo. Por mais cuidados que tomasse, teve de sair da França por se sentir ameaçado, viveu por anos na Holanda, que era mais liberal, mas por fim se sentiu em perigo lá também e foi se refugiar na Suécia, onde acabou sendo envenenado. O mais provável suspeito era um emissário do papa, mas não há certeza sobre isso ainda. Em vez de ficar discutindo geometria ou aritmética primária como modelo do claro, distinto e simples (algo que as duas há muito já deixaram de ser e ele próprio mostrou isso), é preciso discernir o modelo subjacente, o catecismo católico. Este continua vigente, não só entre as pessoas simples, mas inclusive entre intelectuais que supõem ser esclarecidos. Torna-se suspeito quem duvida. Aceita-se a dúvida em questões menores, não, porém, nas "verdades da fé" (que não são verdades no sentido de algo que possa ser demonstrado e comprovado, e sim meras crenças). Quando muitos repetem a mesma crença, gera-se uma coação e o espírito de rebanho se sobrepõe à razão.

Para Descartes, um quilógono ou um miriógono, como figuras geométricas de mil ou um milhão de lados, são claros no conceito, mas não na imagem, o que daria a superioridade do conceito sobre a imagem. Pascal que achava que Descartes gostaria de se desfazer de Deus com um piparote depois de tê-lo usado como impulso inicial das coisas - achava que a imagem é muito poderosa na vida pessoal e política, mas ela por si não era garantia de verdade: pelo contrário, tendia a encenar o contrário daquilo que ela encobria. A simples inversão não era, porém, garantia de sua verdade. As próprias palavras, ajustadas ao contexto em que são empregadas, servem para encobrir o que as coisas são.

O matemático Pascal retirou a confiança cartesiana no matemático. A distância de zero a $\infty$ seria uma distância, portanto, $1=\infty$, o que seria um contrassenso. Pode-se acrescentar a isso que $3-2=1$, mas que há uma infinidade de números possíveis entre 2 e 3 , o que levaria novamente à equação $1=\infty$, contraditória. Caso se proponha $10 \div 2=5 ; 10 \div 1=10 ; 10 \div 0,1=100$; $10 \div 0,001=10.000$, o que permitiria concluir que $10 \div$ $0=\infty$. Caso se proponha $50 \div 2=25$ e assim por diante, chegar-se-ia à conclusão de que $50 \div 0=\infty$, o que redundaria que $10=50$, já que ambos seriam iguais a um terceiro termo, o infinito. A lógica analítica formal da matemática leva ao ilógico.

Se eu elevasse zero à potência $\infty$, eu teria de concluir que o resultado seria zero, com um sinal de igualdade, mas um zero não elevado ao infinito não é idêntico a um zero que tenha passado pela potenciação ao infinito, portanto, não $0=0$. Assim também $1=1$ faz os dois 1 parecerem iguais, mas o primeiro 1 só obtém a sua identidade como sujeito ao ser predicado pelo segundo 1, de maneira que só com o segundo 10 primeiro consegue sua identidade: o segundo 1 vem antes do primeiro e o primeiro vem depois do segundo: o primeiro é sujeito e o segundo é predicado, o que os torna não idênticos, portanto não se pode dizer 1 = 1 . Sujeito e predicado não são o mesmo.

Na correspondência de Leibniz aparece a questão de saber quanto seria o $\infty$ final na seguinte conta: $1+1$ $1+1-1+1-1(. .)=.\infty$. Ele admitiu que o resultado poderia ser 0,5 , pois estaria entre +1 e -1 , mas as opções nessa conta são apenas 0 ou 1 , o que daria como resultados ou 0 ou 1. De um modo ou de outro, 0 ou 1 seriam iguais a $\infty$, o que seria um contrassenso. A lógica analítica formal não se sustenta plenamente como lógica.

\section{Lógica da poesia}

Um poema, vamos tomar o haicai como exemplo diminuto de obra de arte, não é a corporificação de uma ideia prévia. Ela se desencobre enquanto ele se faz. Ele se faz como premonição, sensação interior de algo significativo em imagens e palavras que ficam vagando no fundo da mente, como se buscassem expressão num estado entre vigília e dormência, mas que precisa de atenção concentrada para ser executado.

Assim como o sonho rememora cenas da véspera, combinando-as com imagens mais antigas, para desvendar e desencobrir nelas seu sentido simbólico, o haicai, como uma forma mínima do poema, aflora de uma íntima consonância entre fenômenos da natureza, ritmos e palavras, para sugerir algo que se 
começa não sabendo bem o que é, mas que vai se mostrando enquanto se perfaz. Ele nunca está bem pronto, não é "perfeito", pode ser retocado aqui e ali, mas sempre espera o toque do leitor, que vai fazer dele algo diferente do que era para o autor. Sua síntese dispensa enredos longos ou diálogos. Ele se conclui com a maior brevidade, como se tivesse vergonha de estar tomando tempo alheio numa época apressada. Ele não quer resolver o cosmos no heterocosmos que constitui, mas quer ser abrangente no pequeno: macroestrutura na microestrutura.

O autor sabe que, quando escreve "eu”, esse eu será lido, se for, por um leitor que vai fazer do eu um tu, transformar em seu próprio tu esse eu transmutado. O eu se torna um tu já na leitura, mas o autor também pode já se olhar de fora e se dirigir a si mesmo como um "tu": assim, quando parece estar discordando de outros, pode estar em profunda discórdia consigo, já no sentido de se ver de fora, como se já não fosse mais aquele do qual discorda. $O$ eu se torna um tu assim como o tu pode ser um eu. 0 eu do texto não é o eu do autor.

A lógica do poema não é analítica, por mais que seja precisa em suas análises. Nela A não é $=A, 1$ não é $=$ 1, e 2 + 2 não é $=4$. Se a mesma palavra vem antes ou se ela vem depois, isso não é o mesmo, não é $A=A$. Se ela se repete, não é igual a si mesma: já tem nova nuance. Se A na metáfora sugere B, C e D, não é, porém, mera ambiguidade ou polissemia, mas a busca de um sentido além da significação habitual das palavras. O poema é mais preciso e exato que a aritmética, que finge ser igual o que é apenas semelhante, supondo que pode descartar a diferença como se ela fosse desprezável. A boa arte é mais exata que as ciências exatas.

Assim como o eu textual não se confunde com o do autor nem com o do leitor, também as imagens que aparecem - gaivotas, barcos, formigas - não são idênticas às coisas reais: carregadas de simbolismo, são elas, mas também algo além, algo mais, diferente, em que um sentido oculto se esconde e é a real razão de serem aventadas. As figuras de linguagem são uma traição ao significado literal das palavras. Elas são movidas por um sentido que lhes dá dinâmica e conexão.

O signo não é feito aí só de significante e significado, mas de um espírito que o move. Há um estranhamento da palavra em relação a si mesma. As coisas não são apenas significadas por signos: elas portam em si uma significação, que gera palavras e cenas. Cada coisa significa aí algo outro, que não é mera alegoria, pois esta tem uma ideia pré-fixada, enquanto na cena aventada pelas palavras se encena um sentido novo, que não é apenas o oposto do significado habitual (como na ironia).

Se os haicais resultam de uma busca obstinada entre sombras, precisam transformar sua inquietação na calmaria de uma forma verbal que parece espontânea, pois é a mais exata para sugerir o que eles querem. Tendem a surgir como produtos prontos à mente do autor, que é apenas quem transcreve o que foi ditado dentro dele por força de circunstâncias externas e vocações íntimas. Ainda que explorem rimas, assonâncias, repetições rítmicas ou similitudes verbais, eles não são a mera projeção do princípio de equivalência do eixo paradigmático sobre o eixo sintagmático, pois não há para eles "equivalências": umas "coisas" não "valem tanto quanto" outras, as distinções são selecionadas justamente por sua diferença na semelhança, fazendo inclusive que o maior grau de semelhança sirva para destacar contraposições. Não há sinônimos, a mesma palavra não é igual a si mesma em diferentes posições textuais. Há, porém, assonâncias, consonâncias, ressonâncias: ecoando entre si, as palavras buscam algo que as transcende, mas que transparece nelas.

Por vezes, a ordem dos versos teve de ser refeita, alguma palavra eliminada, outra buscada. Quanto menor o texto, mais exato ele precisa ser. Cada detalhe se torna grande. O haicai sugere algo maior que ele. Macroestruturas estão em suas microestruturas. Cada um é uma fagulha de passagem, uma centelha que é mantida acesa pelas palavras. Não desenvolve um enredo, embora registre uma transição densa, em que o presente revisa, revisita e revista o passado com a premonição de algo vindouro que seja relevante.

O "belo" aí não é a aparição sensível de uma ideia ou de uma verdade prévia, que só buscaria um corpo em que se apresentar, corpo que poderia ser dispensado em sua mortalidade para que a noção abstrata resplandecesse em glória. No ôntico do haicai se tem uma apreensão privilegiada do que o transcende, de algo que não é ontológico no sentido da existência $a$ priori de um mundo das ideias ou dos ideais. Tudo nele é concreto, mas tudo foge à mera concretude singular, isolada. Cada haicai "resvala" para outros haicais, com os quais está num diálogo multifacetado, formando constelações com os que lhe são mais próximos, mas se combinando também com os que lhe são opostos, mais distantes, diferenciados. 
Isso está contido em sua gênese, que procura captar e condensar algo fugidio, mas de caráter único, que se não for apreendido num exato momento há de escapar para sempre. $\mathrm{O}$ escritor é um caçador de palavras, mas ele não as quer mortas nem enjauladas. Ele apenas as traz para serem exibidas ao leitor, seu companheiro de jornada.

O haicai se inscreve com tal força que a escrita é chave para uma libertação provisória, busca que induz a encontrar novas disposições verbais. Forças se reúnem, sentimentos se adensam, razões criticam imagens e palavras, reflexões se autocriticam, até que uma nova disposição de palavras se gera em novo poema. Cada um é uma saída para um novo impasse, que exige nova saída. O instantâneo de sua apreensão é mais que uma fotografia da alma, múmia de um momento: ele é um sopro cristalizado, o mel guardado no favo da página como um pequeno sol a iluminar convivências.

Cada um é o registro de uma transição, carimbo de uma fronteira ultrapassada. Ele se abandona assim que se inscreve no autor e é transcrito. Ele é a lápide de uma vivência que passou. Deve conter algo raro, precioso. Ele é o mapa de uma pequena mina. Se inimigos provocam dor, se amigos provocam decepções, se há encontros afortunados, o haicai vai registrando a variada paleta da existência, mas de maneira que se torne um presente dado aos que se dispõem a ter um encontro: ele é um aperto de mãos.

Se o público vai saber discernir a validade do que ora se apresenta, não se pode saber. O livro vai precisar do apoio dos que puderem apreciá-lo. Por mais difíceis que sejam os tempos, para que boas obras se preservem é preciso haver minorias esclarecidas capazes de perceber sua relevância e preservar sua existência. Muitos escrevem, poucos são os chamados. O texto precisa ter mais força do que quem o escreve. A obra se obra pelo autor. Ele é feito por ela, tomado por algo que o domina e que deve ir além dele.

\section{Metafísica da matemática}

Pascal participou na invenção de duas máquinas, de cujo sentido metafísico se perdeu a noção: a calculadora e a roleta. Se o universo é feito de geometrias e elas são redutíveis a fórmulas matemáticas, se a máquina de calcular chega sempre a os mesmos resultados em operações idênticas, nela não existe o imprevisível: tudo é determinado mecanicamente. Não há, portanto, liberdade. Se o homem é destituído de arbítrio, ele não pode ser responsabilizado pelo que faz ou deixa de fazer.

Embora a roleta tenha sido criada para o divertissement da aristocracia francesa, uma classe parasitária e ociosa, ela resulta também de uma aposta metafísica. A famosa "aposta de Pascal" dizia que, se não sabemos se há vida depois da morte, teríamos de admitir 50\% de chance para haver e 50\% para não haver. Se o sujeito apostasse que não teria, e acabasse havendo, ele iria para os quintos do inferno, pela eternidade fritando no fogo uma alma sem corpo; se apostasse que iria ter e não houvesse, ele nada perderia (exceto a própria vida, desperdiçada em práticas religiosas inúteis); se apostasse que não haveria e não houvesse, nada ganharia (exceto sua única vida, acrescento eu); se apostasse que haveria, e houvesse, ele teria chance de ganhar a vida eterna (um conceito autocontraditório, pois a vida sempreé finita, nunca eterna). Pascal achava que, sem a crença em Deus, o homem cairia numa angústia terrível, que não o deixaria viver.

Dentro dessas opções, o sofisma o induziria a apostar que haveria, mesmo desconfiando que não houvesse. O problema está no pressuposto de que somente haveria um deus verdadeiro, o católico. Disso derivam os 50\%, uma chance em duas. Como a humanidade criou, porém, milhares de deuses, o sujeito poderia acabar topando com outro deus que não aquele para o qual havia apostado. A chance não seria, então, mais de 1 em 2, e sim 1 em milhares, multiplicados ainda pela chance de haver ou não. Ele poderia topar com o deus errado, fulo da vida por não ter sido reconhecido como verdadeiro. Não entrava, porém, na cabeça de Pascal que não houvesse somente um Deus único e verdadeiro, o católico (ainda que não jesuítico).

Mesmo que não fosse o deus errado, sendo o adorado um ente perfeitíssimo, $A=A$, seu juízo seria sempre necessariamente diverso do humano. Era o que acreditavam os jansenistas: que o saber infinito de Deus sempre chegaria a conclusões diferentes das humanas. Estava-se, portanto, nas mãos de Deus, poderosas. A vida era uma loteria, em que mais se tinha chance de perder do que de ganhar.

A noção de ente perfeito é contraditória, pois todo ente foi feito, portanto passou de um estado para outro, de uma imperfeição a outra. Quem fosse perfeito nada poderia fazer, pois para fazer é preciso passar de um estado a outro. Se ele fizesse algo, ingressaria na temporalidade e deixaria de ser eterno. Mesmo Cristo, tendo nascido 2018 anos atrás, mais ou menos, estaria 
longe da eternidade, assim como estaria longe a alma que nasce a cada nascituro. Mesmo a iconografia cristã é contraditória, pois flagela corpos, sendo que apenas a alma seria imortal e não haveria corpo a flagelar, pois mesmo o Dia do Juízo Final não teria ainda ocorrido para haver a reencarnação dos corpos.

O problema estético precisa ser redefinido a partir da cessação da duplicação metafísica do mundo. Que a maior parte dos professores não consiga entender isso, que eles fiquem se sentindo violentados pela profanação dos "valores mais sagrados", isso dá para entender. Compreender sua incompreensão só é possível, porém, com uma radicalização que os ultrapasse, ou seja, é preciso pegar o problema mais pela raiz. Esse modo inusual não foi desenvolvido por Heidegger, Derrida, Gadamer, Paul de Man e outros.

É um problema em aberto, a ser posto para ser resolvido. Pobre, porém, de quem ousar se enfiar nele. Vai semear inimigos. Os técnicos das várias artes não vão conseguir enfrentá-lo. Não é um problema técnico. A técnica aparenta voltar-se para o ontológico ao se propor como ciência aplicada, mas ela se perde no ôntico, que é o seu horizonte próximo de aplicação.

A filosofia parece mal aparelhada para enfrentar essa questão. Ela se constrói sobre a separação entre o ôntico e o ontológico, mas o que a poesia propõe - e o haicai é sintomático disso quando se volta para fenômenos da natureza em que detecta um sentido simbólico - é que deve haver não uma contaminação de vetores separados e sim uma "copresença", uma união hipostática do universal com o singular, como na figura de Cristo, em que se supunha haver ao mesmo tempo o homem e o deus, o singular e o transcendental. O singular se transcende, mas é preciso que ele saiba dizer isso, saiba mostrar.

Quando o escultor discerne no bloco de mármore a estátua que ele quer fazer e passa a tirar da pedra tudo o que não seja a estátua, ele está lhe dando um poder de significação que a pedra por si não tinha. É exaltar a transcendência contida no ôntico, gerando um novo ente, com uma carga ontológica que ele não tinha antes. Faz-se de um ente outro ente mais significativo: há uma mudança ôntica, mas se faz também um deslocamento ontológico, pelo qual o que antes era pedra, mármore, passa a ser um "Moisés", um Laocoonte. Para ser mais preciso: quando se diz que a escultura é determinada personagem, está-se fazendo uma antropomorfização religiosa - cristã ou helênica, pouco importa - que interpõe uma figura mitológica entre a pedra esculpida e sua significação, passando ela a significar apenas aquilo que se projeta.

O próprio ente é transcendente. Sua generalidade de pedra ou mármore não lhe basta. 0 que o escultor fez foi destacar o significativo, fazendo com que aquela pedra fosse mais do que milhares de outras pedras amorfas semelhantes. Não lhe basta também a generalidade de ser uma entre milhares e milhares de outras esculturas, milhões de obras de arte. Aquele ente quer ter um caráter único: ser ele e somente ele. Quando um artesão se põe a fazer variações sobre o mesmo, carreteis e mais carreteis, gatos e mais gatos, cafeteiras e mais cafeteiras, burricos e mais burricos, anzóis e mais anzóis, ele está abdicando de ser artista, pois o que ele faz não tem caráter único, ainda que uma peça não seja totalmente idêntica a outra: ela não é, porém, significativamente diversa, com uma carga significacional que as demais não apresentam.

\section{Deus e o infinito}

Se o signo do infinito é uma contradição, em que ele nega o que ele afirma, nos espaços e tempos da infinitude só poderiam haver finitudes. Deus é uma necessidade lógica: aquele que poderia pensar não somente os espaços infindáveis, mas a infindável variação de possibilidades existentes ao longo dos tempos. Para "ver" isso, seria preciso ser finito, antropomórfico. "Deus tudo vê" é um contrassenso.

Aristóteles fez uma observação simples: nenhum ente pode ser o ser. Todo ente é o que ele é, não pode ser o que ele não é, não pode ser todos os outros entes juntos. O cristianismo fez, porém, a aberração de acreditar que um ente determinado fosse o ser. Para que não se pudesse vê-lo, embora pretendesse ser infinito, tiveram de escondê-lo num mundo "transcendental", separado do mundo terreno.

O problema está, portanto, no modo como se entende o transcendente. Cada ente vai além de si, seja porque lhe toca, seja porque se mostra, seja porque é semelhante ou diferente. Todo ente se transcende, não há "ab-soluto", algo separado, dissolvido de qualquer relação. Se todo ente tem algo nele que vai além dele, ele é conectado com gêneros e espécies mais amplos. Em todo ôntico há, portanto, o ontológico.

Hegel observou que aquilo que faz de um cavalo um cavalo está contido em todos os cavalos. A essência de ser cavalo, a cavalidade, está contida em todos os entes que são, foram ou serão cavalos. A essência não 
precede a existência, ela está contida nos entes existentes. $\mathrm{O}$ abstrato é concreto, ele não paira num mundo além, seja das ideias, seja das abstrações, seja de deus, mas está presente já nas coisas, nos entes, e é neles que precisa ser captado.

Isso coloca um problema difícil para a obra de arte. 0 que vai distingui-la? A tradição filosófica afirma a obra como associação de algo físico com uma dimensão espiritual. Essa é a transposição da concepção de homem como formado por corpo e alma. Aquino diz que o belo é a aparição sensível da verdade; Hegel, que ele é a aparição sensível da ideia; Heidegger, que é uma coisa, não um instrumento utilitário, na qual se revela a verdade entendida como alétheia. Percebe-se em todos uma dimensão corpórea em conjunção com uma dimensão "espiritual", uma alma, que se diz verdade, ideia. É preciso repensar a concepção de homem, para daí entender menos mal a arte. Para entender o homem, é preciso rever os conceitos de cosmos e de deus.

Aristóteles fez, sem querer, um dano à filosofia, ao registrar que, como nossas percepções se dão num âmbito limitado, ele chamaria de "theos" isso que ficaria além. Seguramente ele não estava pensando em um deus cristão nem judaico. É provável que nem nos deuses gregos ele acreditasse. Então theos era um nome provisório, para algo que não podia ser nominado. Era, porém, uma extensão daquilo que nós conseguimos captar e, nesse sentido, não precisaria ser muito diferente do usual.

Descartes assumiu a hipótese católica de que o homem seria constituído de corpo e alma. Daí propôs que corpo seria uma "res extensa", uma coisa com extensão. Em contrapartida, a alma não teria corpo nem extensão, sendo indivisível. No escrito póstumo Paixões da alma, registrou, porém, que, se dois soldados estão sob canhoneio, um fica medroso, pálido e vai se esconder, enquanto o outro fica raivoso, vermelho e se dispõe a sair pelo campo aberto em busca do inimigo. Ou seja, suas reações são antitéticas. Como a reação depende do que se chamava de "alma", tendo esta origem divina, a mesma causa não deveria provocar dois efeitos tão divergentes, o que leva a duvidar da origem divina da alma. Cada "anima" percebe a situação, tem inteligência, tem uma reação afetiva - medo ou coragem - e tem um modo de mostrar sua vontade, se escondendo ou avançando. Além disso, diria eu, há também uma somatização, na cor pálida ou vermelha do rosto, para não falar de outros detalhes.
A intelecção corresponde à figura do Espírito Santo, que é o princípio da inteligência na Santíssima Trindade (afinal, nem Deus Pai se mostrou inteligente ao fazer o homem nem o Filho se mostrou achando que iria salvar toda a humanidade), a reação afetiva corresponde então à figura de Cristo, enquanto a parte volitiva corresponde ao Deus Pai, que mandou as coisas se fazerem, comandou o povo judaico, mandou o filho salvar a humanidade. A Santíssima Trindade corresponde, portanto, à representação mítica de três instâncias da "alma". Acrescente-se aí que há também um processo de somatização, ou seja, o espírito se torna carne e passa a habitar entre os homens, o que corresponde ao que se diz que teria sido feito pela Virgem Maria ao parir Cristo. Aí estão as quatro principais divindades do catolicismo. São instâncias da alma. Esta se divide, portanto, em quatro partes.

Isso significa que a contraposição entre corpo e alma, da qual Descartes havia partido e que é o centro da doutrina cristã, foi superada pelo próprio filósofo. 0 corpo como res extensa teria como contrapartida a alma, cujas características deveriam ser antitéticas ao corpo. Por isso a alma seria o "1", a unidade das unidades. Se ela, porém, se divide em quatro partes, com funções diferentes, a própria definição de corpo como extensão teria de ser revista. Foi o que tentou Leibniz, supondo que haveria uma unidade mínima, a mônada, que seria como que uma centelha energética. Se tudo está cheio de "almas", ela própria como diferencial humano perde o sentido.

Kant chegou ao mesmo problema na primeira edição da Crítica da razão pura, mas houve uma tal reação dos pietistas (não petistas, como quis meu corretor) que, tendo falecido o seu protetor Frederico, O Grande, e ele querendo se tornar reitor, resolveu tirar mais de cem páginas. Qual é o problema? Se cada um é um eu, cada um é um 1. Essa unidade lhe é dada pelo que se chamava de alma, que é o que anima o homem e o faz ser humano. Quando se examinam, contudo, os eus empíricos, percebe-se que cada um é diferente do outro, portanto 1 não é $=1$. Como é que a alma pode ser ao mesmo una e divisa? Una e múltipla?

Por baixo dessa questão da definição do homem como constituído por corpo e alma está a questão, para nós, do modo de entender a obra de arte. Nesta é projetada a teologia antropológica, de tal maneira que nela se acaba "encontrando", disfarçado, o ser humano. Quando se diz que o belo é a aparição sensível da verdade ou da ideia, ou que a obra de arte é uma coisa não utilitária em que se revela a alétheia, o que se tem sempre de novo é a definição do homem. Mesmo 
quando os românticos alemães, como Tieck, Jean Paul, Hegel, insistiram na figura da ironia, o que eles estavam catando era uma definição tripartite do homem como formado por corpo, alma e espírito. $\mathrm{O}$ estranhamento dos formalistas russos é muito próximo da ironia, uma figura retórica que reverte o caráter mimético, fazendo com que o sentido da obra deixe de ser igual ao significado verbal.

A divisão tripartite do homem não resolve a dicotomia corpo/espírito, pois alma e espírito são vistos como entes não corpóreos. No máximo se admite que sejam luz. Embora se reconheçam as funestas sequelas de doenças como Alzheimer e câncer cerebral, não se chegou ainda a admitir que a mente pode morrer antes do corpo, ou seja, a "alma" é mais finita que o corpo, tanto que este dura dias mais que ela. A morte é vista não mais como cessação de batimentos cardíacos, pois estes podem ser mantidos por máquinas, mas como morte cerebral. Nesse sentido, a dita alma é mais finita que o corpo.

A estética do classicismo se fez toda sobre uma visão falsa das obras greco-romanas. Achava-se que eram brancas, sem cores, o que não é verdadeiro. Hegel chegou ao ponto de dizer que suas esculturas não tinham olhos para não verem a própria nudez. Ora, elas tinham olhos, só que feitos de pedras semipreciosas, que foram as primeiras a serem roubadas e a cair. Ridículo é fazer esculturas imitando o modelo clássico e, para isso, deixando as figuras humanas sem braços, somente torso. Elas não foram feitas assim. Os antigos lamentariam ver o estado em que se encontra a maioria de suas esculturas. Imitar os prédios antigos literalmente também não é adequado, quando se tem possibilidade de sustentar teto e telhado com colunas bem mais estreitas do que eles precisavam. É um fetichismo que domina Washington, porque os americanos queriam ser os novos gregos, a dominar o mundo.

O problema estético não se resolve na estética, assim como a filosofia não avança se presa a pressupostos teológicos. Estes, por sua vez, tendem a camuflar motivações políticas, destinadas a manter a exploração do trabalho coletivo em benefício da minoria. É preciso despir os filósofos de sua arrogância de acharem que são os donos do que seria a arte, pois seriam os pensadores fundantes de tudo. Eles se acham donos da verdade, mas não enxergam a verdade de sua ideologia. Em geral, com exceção de Platão, Pascal e Nietzsche, eles também não têm a vivência interior do fazer artístico, uma noção concreta clara de como é compor, escrever poemas, fazer esculturas, pintar. Eles acham que sabem tudo, mas não tem boa noção interior da arte. A arrogância os impede de ver seus pressupostos e suas limitações.

\section{Ôntica e ontologia}

Tendo Aristóteles dito que nenhum ente é o ser, mesmo que os escolásticos o tivessem tomado por mestre, eles não o seguiram nisso. 0 importante não é, aliás, que ele tenha escrito isso, mas que seja lógico o que diz. 0 deus cristão, considerado sumo bem e o ser dos seres, não é idêntico ao Jeová do Antigo Testamento, uma divindade vulcânica e do deserto, privativa de um povo. Quando os cristãos o fizeram ter um filho, geraram nova divindade, que não foi aceita por judeus e muçulmanos. Nos tempos modernos, o Deus do terror ou solar medieval mudou de perfil, passando a corporificar a infinitude, o que é uma contradição (um corpo, para ser corpo, precisa ser finito, pois precisa ser delimitado, sendo o que é por não ser o que ele não é).

Ele passou a ser um signo matemático, o infinito no espaço, tempo, saber e poder. Saber só tem sentido em função da ignorância: saber infinito não tem noção do que sabe, pois nem sabe o que é saber, já que não sabe o que é ignorância. Poder só adquire sentido em função das resistências que pode vencer: quem tem poder absoluto não sabe o poder que tem. $O$ infinito no espaço precisaria ser todo o espaço, abrangendo, portanto, o mal chamado universo: se não o abranger, já não será infinito, pois o infinito menos a infinitude dos espaços siderais não poderia ser infinito, já que está excluído de tudo o que existe (ou, caso se confunda com ele, funde-se e já não é mais um ser distinto). O infinito no tempo não teria noção do tempo, pois precisaria estar fora dele, numa eternidade em que nada transcorre, mas um deus que se ponha a criar mundos, conviver com Adão, fazer filho numa virgem judaica, olhar o filho na cruz e assim por diante está dentro do tempo, e o que está dentro é temporal, não pode ser eterno. Bobagem é também achar que no céu se estaria cantando aleluia e contemplando a grandeza do Senhor por toda a eternidade: isso seria contraditório.

Quem fosse infinito no espaço não teria noção do espaço que ocuparia, quem fosse infinito no saber não saberia o quanto saber teria, quem fosse eterno não poderia fazer nada no tempo e, portanto, não poderia criar nem mudar nada. Um deus que não soubesse a sua extensão no espaço ou no tempo não poderia ser onisciente. Se esse Deus se metesse na vida dos homens (e das donzelas), ele não poderia 
ser eterno nem infinito, pois teria de tomar formas de finitude. Esse deus é pura contradição e, pior, ele é uma impossibilidade lógica. Querer inibir a consciência disso dizendo que se trata de algo acima da compreensão humana é apelar para um autoritarismo que pretende anular a racionalidade em função da crença.

\section{Da identidade e da diferença}

Por que a escolástica e seus influenciados da lógica analítica insistiu tanto na noção de $A=A$ ? Porque Deus seria $A=A$ : eu sou aquele que é. Ele seria autoidêntico por toda a eternidade. Perfeito seria o que não muda. Alguém assim não poderia criar o mundo: passaria de um estado pré- para um estado póscriação: teria de optar entre ser perfeito antes ou depois. Criar é entrar no tempo, estar no tempo é mudar, é não ser perfeito nem eterno. Assim como a alma estaria no tempo se o seu portador mudasse com o tempo, digamos, se arrependesse.

Se Deus fosse onipresente, ele não poderia saber onde estaria, pois espaço é algo que se sabe por espaçamento, por distanciamento entre corpos. Quem não tivesse distanciamentos não poderia ter noção do que é espaço. Se Deus fosse infinito e tivesse criado um universo infinito, ele não poderia ser o que ele teria criado e seria, portanto, infinito menos infinito, o que não poderia ser infinito. Se ele fosse tudo o que há, ele seria tudo, e tudo seria divino e maravilhoso. Esse panteísmo acaba dispensando a figura de Deus, pois ele seria tudo e, portanto, nada seria ele, ele seria nada.

Só se tem algum poder quando se podem vencer com ele resistências; só se sabe algo, quando se passa do estado de ignorância ao de conhecimento. Um ente onipotente não poderia sofrer nenhuma resistência, portanto ele não saberia o poder que tem; quem já sabe tudo não sabe tudo o que sabe, pois não ultrapassa nenhuma ignorância. Ou seja, se a característica de Deus fosse A como onipotência e onisciência e ele não pudesse ter noção do que pode e sabe, ele seria também não-A. Ou seja, ele seria $+A=$ $-A$, ou $A=$ não $A$, um ente contraditório em si, não podendo ser fundamento último do juízo analítico.

Fichte ${ }^{6}$ observou ainda que, se digo $A=A$, o segundo A é uma predicação do primeiro, que é o sujeito. Então a frase contém uma contradição em si, pois diria que sujeito e predicado são o mesmo. Hegel disse que o segundo A determina a identidade de A como A e, portanto, o primeiro A só se firma e afirma como $A$ depois do segundo A, portanto ele secunda o segundo.
Quando se diz “É", ou "é igual”, está-se supondo algo que não muda. Daí a necessidade de afirmar a verdade como o imutável. É um modelo teológico, que domina ainda hoje a ciência. Domina também a arte, pois se supõe que uma obra clássica, digamos, seria idêntica a si mesma, seria a mesma em todos os tempos e lugares.

O que os escolásticos não permitiram fazer, mas os filósofos dos séculos XVII e seguintes até hoje não fizeram, foi explicitar que o Deus cristão é " $A$ = não A", ou seja, que ele contém a contradição em cada uma de suas características e, portanto, não poderia ser perfeito. Ele também não poderia ser modelo para a perfeição da obra de arte. Que Alberti tenha postulado a perfeição como aquilo em que não se pode tirar, acrescentar ou modificar algo é compreensível, sabendo-se que era bispo, católico, secretário de obras do papa. As obras se modificam pelas novas relações que se estabelecem com novas obras e leituras que vão surgindo ao longo do tempo.

Por que tantos intelectuais inteligentes e tantos bilhões de pessoas não percebem uma contradição tão evidente? Porque elas não conseguem aceitar que irão morrer, deixar de ser. O problema não está na contradição evidente de Deus, mas nas contradições de cada ser humano. Se ele vai morrer, a morte já está nele. Assim como ele está aí, está nele que ele não esteve e não estará mais aí. Embora qualquer um possa morrer a qualquer momento, envelhecer é evidenciar em si a proximidade crescente da morte. 0 que somos contém em si não só que poderíamos ser algo outro, mas que iremos deixar de ser. Cada um de nós é o A que vai ser não $A$, porque já tem em si o não A porque ele está sendo um certo $A$.

Jan Mukařovsky propôs que se visse a relação comunicativa na arte: o artista é o emissor, que produz um artefato artístico, o qual, na sua ausência, se torna uma coisa, um suporte material de artefato; o receptor, ao captar esse suporte material, recria a obra fazendo um objeto estético. $\mathrm{O}$ autor é o primeiro a perceber a obra, pois enquanto ele está fazendo o artefato também é o primeiro receptor dele, o primeiro a ler sua produção e poder assim aperfeiçoá-la: ele produz a obra porque é também o seu primeiro receptor. Quando ele se vai e fica apenas o suporte material, o receptor precisa recriar a obra, e a que ele vai produzir para si não é idêntica à do autor, pois ele não é o autor primeiro, ele é um coautor.

Nesse sentido, a obra está em permanente estado de mutação e ela jamais é idêntica a si mesma. Claro é
6

Fichte, Johann. Grundlage der gesamten Wissenschaftslehre (1794), Hamburg, Meiner Verlag, 1997. 
que o sistema de poder canônico trata de impor uma identidade, mas precisa impor porque não há essa identidade absoluta. A maneira de receber obras e quais as que são ativadas pela recepção varia muito conforme os países e as épocas. Como de Deus, não se pode dizer da obra que $A=A$.

Essa noção teológica de infinitude marcou também a estética, supondo-se que as grandes obras estão fora do tempo, valem para todos os lugares, abrigam uma sapiência infinita e são perfeitas. Não há nenhuma obra assim. Essa estética não sabe que é teologia disfarçada. Ela foi rompida, sem querer, pela escola de Konstanz, com sua estética da recepção: em vez de se ater apenas à relação entre autor e obra, como tem sido feito sob a suposição de que o artista seja uma alma iluminada que vem trazer uma luz celestial aos pobres mortais, enfatizou a relação entre obra e receptor.

\section{Ideias claras e distintas}

Se o modelo secreto das "ideias claras e distintas", com que Descartes parecia propor um paradigma matemático de correção científica moderna, parece ser antes o catecismo católico, nele as perguntas mais difíceis encontram uma resposta clara e simples: quem criou o universo? - Deus; de que é feito o homem? - de corpo e alma; quem salvou a humanidade? - Jesus Cristo. Que as respostas não sejam verdadeiras é inadmissível ao fiel. Elas estão corretas dentro do paradigma católico. Heidegger, no livro sobre Nietzsche e em vários cursos, fala da diferença entre correção e verdade, fala de Descartes, mas não entra nisso, que é bastante evidente, ou seja, o modelo catequético católico. Aí a "verdade revelada" e os "princípios da crença" se sobrepõem a qualquer questionamento.

A ciência moderna quer modelos claros e distintos, como a lei da gravidade ou a fórmula $\mathrm{E}=\mathrm{mc}^{2}$, com sua pretensão de resolver de modo simples o universo inteiro. Se os corpos estelares, ao menos da perspectiva terráquea, parecem estar mais se afastando entre si do que se aproximando entre si, como isso não está de acordo com a lei da gravidade, inventam uma explosão inicial enorme, o Big Bang, para explicar esse impulso que esparrama astros. Se, digamos, nem tudo seria matéria, a lei da gravidade só se aplicaria onde houvesse massa e, então, ela não teria validade absoluta. Fórmulas simples ajudam a resolver a angústia humana, não se resolvem fenômenos complexos com regras simplórias.
Verdades da fé x verdades da razão

Se Christian Wolff insistiu, em sua Ontologia, na necessidade de encontrar a razão suficiente de todas as coisas, inclusive da existência de Deus, se até Deus tem de se provar, não bastando mais apontar para a sua obra e exigir reconhecimento, quem não precisa se provar é essa razão, porque ela é a prova de tudo. Qual é, porém, a razão dessa razão? Ela é baseada no princípio da identidade ou no princípio da não contradição. Ela é analítica, em que $A=A$, tudo é idêntico a si mesmo, tendo Deus por fundamento.

Num poema, porém, a mesma palavra não é a mesma dependendo de onde ela aparece, se no começo, no fim como rima, no meio do texto. Toda pessoa sabe que ela é uma flutuação de posições diversas, sendo sua resposta uma ou outra dependendo das circunstâncias. Num sonho, toda imagem que aparece significa algo outro do que aparenta.

Não se discute no século XVIII com que conceito de verdade se estava operando. Parece que se contrapor às "verdades da fé", ou seja, a verdade sem nenhuma comprovação, apenas baseada num texto dito sagrado ou das autoridades de uma igreja, já era mais que suficiente. E era muito. De tudo se exigia uma razão de ser, uma explicação lógica. Era o primado da razão, cujo expoente externo se tornou o monarca esclarecido, talvez antes um déspota a sustentar privilégios do que disposto a ceder suas prerrogativas. Era "óbvio" que a verdade seria a "adaequatio res et intellectus", sem que se perguntasse se isso não seria antes, porém, a adequação de uma imagem mental a outra, sem que a própria coisa pudesse se expor.

Pelas portas dos fundos é que se coloca, porém, a questão da verdade: pela fabulação. Se não se desse o primado à explicação racional, tudo poderia ser resultante da fabulação, conforme registrado por Wolff no $§ 77$ de sua Ontologia. ${ }^{7}$ Por que ele não ousou levar isso adiante? Descartes atribuiu à antiguidade a tendência de fabular coisas inexistentes, "quimeras", mas não ousou dizer que o mesmo poderia ser dito do imaginário cristão. Ele não podia dizer isso. Wolff também não: ele gerou o seu próprio interdito, que estava dentro dele, mas era também algo bem presente nas pessoas que exerciam o poder.

Essa noção da diferença entre o "mundo verdadeiro" e o "mundo fabulado" reaparece em Nietzsche, mas para dizer que se perde a noção de um mundo verdadeiro e, por isso, se evapora também a noção de 
fábula como uma distorção imaginária (Ver Semiótica da cultura, ${ }^{8}$ tradução do texto). No final da introdução à Crítica do juízo, Kant pondera que tendemos a considerar verdadeiro aquilo que está de acordo com a nossa vontade. Algo não é, porém, como é só porque desejamos ou queremos que assim seja. Muitas vezes temos de reconhecer que as coisas e pessoas são de modo muito diverso do que seria por nós desejado. 0 espírito científico sai de dentro de si, da prisão dos seus desejos, e analisa os fatos objetivamente.

Leibniz havia recomendado que se prestasse atenção às imagens obscuras e pouco distintas da mente. $O$ próprio Descartes, no ensaio La géométrie, ${ }^{9}$ havia mostrado como a geometria e sua matemática podiam se tornar cálculos complexos, especialmente quando estes se abrem para a raiz quadrada e a potenciação, de maneira que o modelo proposto em suas obras mais famosas, como o Discurso do método, fica implicitamente questionado. Não se deve confundir matemática com a aritmética das quatro operações. Mesmo estas podem se tornar muito complexas.

Costuma-se dizer que Descartes teria sido uma racionalista. Com isso se perde a noção da tensão que havia no pensamento filosófico em se distanciar da dogmática religiosa. O modelo subjacente à noção de "noções claras e distintas" parece ter sido o catecismo e não apenas a geometria e matemática. O que era para ser uma ruptura com a dogmática religiosa, tornou-se uma nova forma de dogmática, pois só se podia entender o triângulo, o quadrado, o $2+2$ conforme era ensinado nas cartilhas. Era um convite à acomodação, ao não pensar adiante, ao não questionar. Isso como que provocou um cessar do questionamento filosófico na França, enquanto ele na Alemanha se desenvolvia em regiões como o ducado de Weimar e a Prússia.

Nas três metafísicas especiais, a cosmologia foi deixada aos astrônomos, a teologia ficou nas garras poderosas dos padres e pastores, restando no século XVIII aos filósofos a metafísica psicológica. Dentro desta é que afloram estudos específicos como a psicologia aplicada, a estética, a semiótica, a hermenêutica e a epistemologia, como se todas elas fossem estudos da alma, reservada aos humanos. Será que as obras de arte valem só como testemunho do que se passaria no fundo da alma de gênios ou elas têm algo que não é mero documento de uma constelação psicológica? Até hoje, muitas vezes não se publicam certos poemas porque seriam denotativos de fragilidades psicológicas, que não se recomendaria se tornarem públicas. Baudelaire viu no poeta uma prostituta, que dá acesso, pela venda dos poemas, de sua intimidade a quem pague por isso. Quando se publica algo, em geral isso já não é mais uma fragilidade interior e sim uma constelação ultrapassada.

\section{Wolff e Baumgarten}

Wolff e Baumgarten desenvolveram "categorias" para o estudo do que se passaria no "fundus animae", no fundo da alma. Wolff tem capítulos sobre sensus, imaginatio, facultas fingendi, memoria. Baumgarten acrescenta perspicatia, praevisio, iudicium, praesagitio, facultas characteristica. $^{10}$ São bastante óbvias e consistentes. Chama a atenção que a mente não é vista apenas como operando entre presente e passado, mas também em relação ao futuro, com a capacidade de previsão e do presságio. Qual é a faculdade mais relevante?

Pela imaginação o homem transmite sinais dos sentidos para a mente, recupera sinais pretéritos, é capaz de transfigurar dados para torná-los mais significativos, pode comparar dados presentes com dados mais distantes e assim ver além das aparências, é capaz de prever o que vai acontecer no futuro próximo, mas também é capaz de ser tomado por prenúncios que pressagiam o que ainda há de acontecer. A psicanálise de Freud prestou atenção especial ao passado, à relação entre neuroses do presente com traumas do passado, deixando os presságios para o âmbito das especulações e crendices. Jung viu no sonho uma capacidade de retomar cenas de véspera para ver nelas o sentido simbólico e servir de alerta para dados que não haviam sido atentados, funcionando, portanto, como um anjo da guarda do sujeito, advertindo sobre o vindouro próximo.

A "facultas fingendi" parece fazer da imaginação, fazer de conta que está aí o que não está, fazer de conta que é real o que não é. Fingir é visto como algo negativo: falsear, falsificar. Se não parece ser este o sentido, por que não usou um termo faculdade inventiva? O modelo que ele tem de verdade é a da lógica abstrata, analítica. A estética vai ser um "analogon rationis", um análogo da razão, não a própria razão, a razão propriamente dita.

A estética é o território em que vai se dar o questionamento prático da concepção de verdade. Aquilo que a lógica, até Hegel, não permitia que fosse feito em seu território, a inovação e diversidade no
8

Kothe, Flávio R. Ensaios de Semiótica da Cultura, livro de ensaios com prefácio, Brasília, Editora da Universidade de Brasilia, 340 páginas, 2011, ISBN 978-85-230-1283-0, p. 338-339.

9

Descartes, René. La géométrie, Nouvelle Édition, Paris, A. Hermann, 1886.

10

Wolff, Christian. Psychologie ou Traité sur l'ame, Amsterdam \& Leipzig, Schreuder \& Mortier, 1766.

Wolff, Christian. Briefe von den Jahren 1749-1753, St. Petersburg, Kaiserlilchen Academie der Wissenschaften, 1860. 
artístico criou um espaço para outro tipo de lógica. Para os poetas era natural que A fosse B, C, D. Para os arquitetos, as pedras de um templo homenageavam uma entidade divina.

Para Wolff, "perceptiones obscurae" não são boas percepções, são falhas de percepção, mas é de sua natureza serem assim: precisam ser esclarecidas, descobrir sua razão de ser como são, mesmo que não pareçam “lógicas”. Até o absurdo tem uma razão de ser. Lógica tem sido descobrir a ossatura básica de algo complexo. A lógica do poema não é a do princípio da não contradição. A mesma palavra, em diferentes partes do poema, não é a mesma. Em toda metáfora e todo símbolo $A$ não é apenas $=A$, porque significa também não-A: B, C, D. A poesia foge, portanto, ao juízo analítico, ele não é suficiente para ela. Ela exerce a liberdade de sugerir o outro da palavra e de si mesma.

Poder fingir que exista algo que não existe é uma liberdade em relação ao real. Pode-se descobrir seu sentido oculto assim. Se a produção artística, onírica e imaginativa em geral parte de um movimento mimético, ao combinar mais fatores ela deforma o gesto copiativo, para alcançar uma forma que seja mais significativa do que a mera reprodução do original.

Baumgarten propôs que se procurasse decifrar o "fundus animae", mas nos termos de um "analogon rationis", ou seja, o predomínio continuaria a ser da "ratio", cujo modelo seria a razão matemática, a proporcionalidade, a equivalência disso em relação àquilo, às custas do menosprezo do não igual. Tevese como que o cinismo de fazer de conta que era igual aquilo que era apenas parecido; reduziu-se o real a uma dimensão, o quantitativo, e se impôs isso como se fosse uma verdade absoluta. Sob a aparência de desmontar a máquina teológica, criou-se uma nova dogmática. Surgiu daí a Kunstlehre, que não por acaso tem sido traduzida como doutrina da arte, em vez de apenas um ensinamento da arte.

\section{Veritas aestheticologica}

O que seriam esses "princípios verdadeiros" de Baumgarten? O que é a verdade para ele? Por um lado, ele diz que a verdade é o imutável, o permanente; por outro, afirma que a "falsitas aestheticologica" depende do "pius", do "honestum", do "decorum", só que aí precisa admitir que eles possam mudar. Ele cita Cícero, quando este diz que é preciso ser "pio", reverenciar os deuses: ora, eram os deuses romanos, não os cristãos.
É como se cada época tivesse os seus deuses, verdadeiros porque correspondem ao poder. Se o que é falso em termos estéticos depende do que for considerado correto num meio e momento, então a verdade estética também vai depender. Se ela depende, ela não vale por si, mas pelo que ditam as circunstâncias da época e do lugar.

Se o que é falso esteticamente depende de critérios de crença, de moral e de conveniência social, a verdade também depende deles. Ela não é, portanto, verdadeira por si, mas apenas por extensão de quem dita as regras sociais. Não se diferencia aí entre verdade e ideologia. Essas regras variam conforme as épocas, os locais, as classes, os grupos sociais. Uma parte querer se impor como verdade do todo é totalitário, é a sinédoque que perdeu a noção de que ela é apenas parte de algo maior. Querer igualar todas as partes como se fossem equivalentes seria não reconhecer a diferença entre elas, a não igualdade na qualidade do que nelas se produziu em momentos diversos.

Quanto mais regras houver para uma composição artística, mais fácil fica para o computador fazê-la e menos espaço há para a inventividade humana. Já se fez essa experiência com música barroca composta por computador. O ouvido mais refinado percebe, porém, a diferença. De qualquer modo, as profissões são afetadas pela informática, de maneira que novos profissionais terão de saber fazer só aquilo que as máquinas por si não resolvem.

Para Baumgarten (§ 72), a regra superior é sempre mais forte que as regras subordinadas, as leis da estética são mais fortes que as regras das diferentes artes. Elas seriam, portanto, como as normas constitucionais em relação às dos códigos específicos. Mais fortes que as leis estéticas são, contudo, as normas emanadas do poder, sendo este não apenas o governo, mas diversas instituições sociais, como igreja, família, associações.

Nas universidades e institutos de artes e ofícios somente se estudam as "artes" voltadas para a audição e a visão, sem que isso seja problematizado. Cada arte estuda a sua teorização e história, sem desenvolver a comparação com as demais, estudar o parentesco entre elas. Não se estuda a estética enquanto teoria de todas as artes: quando se faz, é apenas para fazer variações em torno de pressupostos teológicos, que são solenemente ignorados. Ela não é a soma das teorias particulares. As escolas e épocas da arte como que se anulam mutuamente à medida que se contradizem e se negam entre si. 


\section{Regras da arte}

Se as supremas normas estéticas são determinadas por conveniências sociais, só existiria nelas a falsidade, não a verdade. Aquilo que se chamaria de belo dependeria das convenções. Cada época e cada escola de arte seria a negação das demais, todas elas se negariam mutuamente e não haveria uma verdade que as permeasse. Seria então mais correto fazer uma sociologia do gosto, uma história do gosto, não uma filosofia da arte. Do mesmo modo, seria preciso construir grandes museus de antropologia, em que todas as culturas do mundo estivessem, na medida do possível, representadas, a pretexto de que todas se equivalem.

Quais seriam essas "regras universais" que dominariam todo o âmbito estético? Kant tratou de defini-las na "Analítica do belo", da Crítica do juízo. Elas parecem universais e eternas, mas não são. Elas estão de acordo com a sua "tabela", mas deixam fora o que lhes convém e são todas elas contraditórias, o que está em desacordo com a proposição "analítica”. Pela "tabela" se discute a finalidade do belo, mas não a origem dele, ou seja, como ele é financiado, como ele circula, qual é a relação dele com o poder. Quer-se dizer que ele existe de modo "desinteressado", com isso não se quer examinar a quais interesses ele serve, sejam eles econômicos, políticos ou religiosos. Fácil fica fazer uma tabela de conceituações, que depois é repetida por professores kantianos de todos os cantos, sem que o imperialismo totalitário subjacente seja discutido.

Baumgarten afirma que "falsa regula semper peior quam nulla" (§ 73), a regra falsa é pior que a nula”. Mas o que é uma falsa regra? Para cada movimento artístico, as regras dos demais não são adequadas. Os manifestos expõem regras, mas as melhores obras não são demonstrações de manifestos. Kant vai como que inverter isso, dizendo que o gênio é o exercício da liberdade (mas também o meio que tem a natureza de impor regras). $O$ gênio é livre para impor novas regras, assim como o sujeito é livre para se impor normas pelo imperativo categórico, o que é uma contradição: ter algo para deixar de ter.

No $\$ 442$ da Estética, Baumgarten afirma que a verdade strictu sensu é o imutante, o imutável (immutata) e, segundo Cícero, conecta com as virtudes (fortaleza, dignidade, coragem, sabedoria). O que era virtude para um militar patrício romano não era virtude para o cristão (compaixão, humildade, piedade, reverência, pobreza de espírito). Por outro lado, a falsidade estética varia conforme o que for pius ou honestum, mas o que é piedoso, correto e honesto vai mudar conforme o grupo social e a época. Se a falsidade varia conforme esses vetores externos, varia também a verdade estética, se é que ela ainda existe. Ficam-se então com dois critérios opostos de verdade: um, imutável; outro, mutante. O imutável é o que aponta para Deus, o princípio da identidade absoluta. A admissão do mutável aponta já para a morte de Deus.

Naquela época - como ainda hoje para a maioria das pessoas - acreditava-se que a alma seria capaz de pensar por si, sem corpo. Como se daria, então, a relação entre corpo e alma quando esta estivesse nele? Baumgarten chega a dizer que a "anima" seria "motus cerebri”, ou seja, a movimentação do cérebro. Isso poderia levar a supor que ele acreditasse que a alma não seria mais que cérebro se mobilizando. № $§ 560$, escreve: "motus cerebri coexistentes animae repraesentationibus successiviis: ideae materiales vocantur", ou seja, movimentos do cérebro coexistentes com representações sucessivas da alma são chamados de ideias materiais.

Como entender isso? Não é a dinâmica do cérebro que provoca para ele representações sucessivas na alma e sim as mobilizações desta é que provocam movimentos no cérebro, como se este estivesse num processo mimético permanente, como que a espelhar no corporal o espiritual. As ideias são aí chamadas de materiais porque se reproduzem no cérebro, ou seja, se admitem ideias que não sejam materiais, isto é, puramente espirituais, funcionando sem a existência do corpo. Só que não há provas disso. Trata-se de mera crença, refutada pela neurologia. O corpo é a região predileta do pecado, enquanto a elevação "espiritual" se daria só na alma.

A "Estética" deve aí a sua existência a essas "ideias materiais". Se há um processo mimético no íntimo da pessoa, em que o espiritual ecoa no cerebral, a obra de arte seria então algo corpóreo que teria por função celebrar algo espiritual, que seria o seu sentido. Que se chame a isso de verdade, de ideia ou de alétheia não faz diferença: está-se sob o mesmo esquema. Não há real progresso.

Baumgarten no $\$ 2$ divide a Estética em "natural”, a faculdade dos conhecimentos de grau inferior, e "artificial", que serve para: 1) fornecer materiais para o entendimento; gnosiologia inferior; 3) conhecimento fora do horizonte do que se conhece claramente. É claro aí que o "corpóreo" é inferior, como se o conhecimento abstrato não fosse corpóreo também. 
É o mesmo problema que se colocara em Platão ao dividir os sentidos em espirituais (visão e audição) e materiais (os demais), que determina ainda hoje o que pode ou não ser considerado arte. Por que esse "nojo" pelo corpóreo se o maior prazer que o homem pode ter está ligado à sensualidade?

A essa "função estética" de natureza corpórea e supostamente inferior está reservada, em Baumgarten, a tarefa de dar sustentação à lógica mais elevada; em Kant, fornecer materiais para o entendimento conceitual; em Hegel, ser o burro de carga das ideias que farão as delícias do filósofo. Hegel chegou ao ponto de achar que a arte estava morrendo, ou seja, não havia mais gênios artísticos: perto dele estavam Goethe, Schiller, Hölderlin, Jean Paul, Tieck, Beethoven, Schubert, Schumann, Mendelssohn e tantos outros. Ninguém valia nada. O belo natural podia ser descartado. Ou seja, a função do estético é a do servo que deve servir ao seu amo e senhor, o entendimento, a razão. Ele é como o serviçal que tem de gerar mantimentos, preparar a comida, arrumar a cama.

O que a filosofia faz é transpor uma estrutura de exploração de classe social, em que a maioria "bruta" tem de gerar seus produtos para o proveito do senhorio. Ela consagra isso como se fosse a estrutura eterna e universal da mente humana. Ensinando-se isso nas universidades, reduplica-se a exploração social como se fosse algo absoluto. Finge-se pensar, para melhor não pensar. A filosofia faz então o que a religião já fazia. Faz o mesmo de outro modo. Precisamos resgatar a arte do seu estado de servilismo.

Não entende de Estética quem só entende de Estética. Nas três metafísicas especiais - do cosmos, de Deus e do homem - esconde-se uma correlação: o modo como se entende o cosmos determina como se entende Deus e o homem. Isso por sua vez determina como se entende a arte. Se o Cosmos é visto como algo criado por Deus, transpõe-se esse divino como alma dentro do homem e Deus fica entendido como criador de tudo. A teodiceia grega antropomorfizava isso ainda mais, com gerações de deuses maiores a fabricar menores e todas as coisas.

O problema nosso é como podemos passar a entender a obra de arte a partir da morte da duplicação metafísica do mundo, da divisão do cosmos em espírito e matéria, do homem em alma e corpo, portanto da obra de arte como tendo uma corporeidade que seja portadora de uma espiritualidade (verdade, ideia, alétheia, complexo, arquétipo ou como se queira chamar). Um passo simples seria supor a obra como miniatura do cosmos (é o que se tem feito) ou do homem (com este também). Seria contraditório supor que o finito da obra pudesse ser uma sinédoque da infinitude. Teríamos de atribuir uma infinidade de sentidos latentes nela. Daí ela não teria sentido nenhum. O que pretende ser tudo é nada. Não tem sentido construir uma obra para ela não significar nada.

De certo modo já se está a caminho disso. Supõe-se que o inconsciente seja imenso, insondável no todo. Estuda-se a poesia hermética para ver o máximo de sugestões de sentido no mínimo de palavras. Os grandes sonhos são plurívocos, podendo sempre receber mais um adendo significacional. A hermenêutica parece inesgotável, a verdade fica, no Heidegger II, zanzando para lá e para cá, se escondendo ao iluminar e iluminando ao esconder.

Baumgarten faz uma valorização do corpo, do conhecimento corpóreo, mas ele não abandona a crença numa alma imortal, que funciona independente do corpo: o cérebro é forçado a mimetizar suas danças. Antes de se largar a teoria mimética - parando de se preocupar em imitar a natureza no sentido de copiá-la para imitar os procedimentos criativos da natureza - tem-se ainda o cérebro a mimetizar a alma.

\section{Conclusões}

Deus não poderia ser onisciente, pois o saber sempre se dá como contrapartida a um estado de ignorância: se não há ignorância nele, há algo que ele não sabe e, portanto, não é onisciente. Quem sabe tudo não pode saber quanto ele sabe, pois não tem sequer noção de quanto sabe, já que não pode saber o que não é saber. A onisciência é, portanto, uma contradição. Do mesmo modo, a liberdade por si, e em si, não sabe o que ela própria é. Ela decorre de um testar os próprios limites, descobrir o que são as normas que ditam o correto, o pio, o honesto. Violar essas normas ainda não é ser livre. Descobrir os limites dos paradigmas do correto não é ainda poder criar algo que vá além. Quem muito se proclama rebelde tende a ser menos rebelde do que supõe.

A grande obra surge do silêncio e ela retorna ao silêncio. Como ela está fora do paradigma, tende a não ser reconhecida como tal. Quando é badalada, pode ser por causa de paradigmas muito canhestros, que o público culto da época pode não perceber como canhestros e sim como o grande ápice do saber da 
época e do lugar. O lugar tende a não perceber que é apenas um lugar, que podem existir outros lugares com perfil melhor, mais elevado. As referências do cânone são sempre pretéritas e, como tais, não estão abertas ao que realmente é novo. Este é execrado, perseguido, não se confunde com a novidade da moda, da vanguarda autoproclamada, da inteligência empoderada. Algo ser tratado assim não é, porém, garantia de que a obra seja genial: o autor pode ser simplesmente um mau caráter. É possível pagar alguém para que fale bem de uma obra, mesmo que ela não seja tão boa.

Estamos examinando a teologia subjacente à estética. Se Deus cria o universo, ele está no tempo como ocorre com qualquer ação, portanto ele não pode ser eterno. Se ele cria a partir do nada, não é um artífice, pois este sempre transforma uma coisa em outra. Se Deus não é o universo que ele teria criado, sendo o universo infinito, ele próprio não poderia ser infinito, pois teria uma infinitude fora dele. Também não poderia ser onipresente, pois para isso teria de estar por todas as partes, não podendo ser essas partes e sendo mais invisível que o homem invisível. Em tantas contradições, ele não poderia ser aquele que é, o fundamento de todo $A=A$. Ele seria $A$ e não $A$ ao mesmo tempo.

Do mesmo modo se supõe que a obra de arte seja auto idêntica, imutável, eterna - um clássico jamais deixaria de ser um clássico -, quando de fato o rol dos clássicos muda, o modo de ler as grandes obras também muda, a ponto de não serem mais as mesmas. Quem está dentro de uma teologia cristã não vai questionar pressupostos que ele toma como verdades absolutas. Ele se considera superior aos "homens de pouca fé", tem pena de quem é ateu ou agnóstico, inventa rótulos que não conseguem abranger a posição que o superou, mas que ele quer manter sob controle impondo rótulos. Marx e Engels usaram o termo ideologia em vários sentidos, mas ficou basicamente o de "falsa consciência", que contém uma contradição: ou é falsa ou é consciência. A consciência tem de ser algo verdadeiro, não tem aí um sentido moral (e mesmo que tivesse somente tem consciência quem quer agir com correção).

Kant disse que o gênio é o exercício da liberdade porque talvez soubesse que ele não tinha toda essa liberdade. Ele próprio sentiu isso na pele quando seu protetor, o monarca Frederico, faleceu. 0 gênio é talvez aquele que mais sente os limites da liberdade. Para o talento, basta executar a partitura que ele tem diante do nariz: ele executa um paradigma, talvez com mais acerto do que um gênio. A obra genial não é necessariamente perfeita, ela pode precisar de uma revisão textual, por exemplo, mas tem mais acertos e vai para horizontes que obras comuns não alcançam. O talento está para o correto como o gênio para a verdade livre.

Quando um Descartes escreve que pode duvidar de tudo, menos da existência de Deus e da alma e de que estivesse duvidando, provavelmente teve de fazer uma grande reverência ao poderio da Igreja ou talvez acreditasse no que dizia, mas o que ficou foi o princípio da dúvida em vez do dogma. O seu modelo de "verdade" foi a aritmética mais simples; sua Lógica, a analítica, embora seu texto ganhe força pelas tensões e contradições internas. Deus era para ele a garantia das operações aritméticas mais simples. Ele tinha certezas na dúvida, mais absolutas que o duvidar.

A herança disso, a pretensão do conhecimento baseado na matemática como sendo "ciência exata" estende a pecha de inexata e imprecisa à arte e às ditas "ciências humanas", cujo modelo está naquela. A arte é mais exata e precisa do que a matemática, que faz de conta que é igual o que é apenas parecido. Um poema ou um conto precisam ser várias vezes revisados, por mais de uma pessoa, e acabam sempre tendo ainda algum defeito, lapso, erro. Estes são percebidos por quem realmente é do ramo. O que a outros parece perfeito, esconde erros diversos.

Quando alguém é treinado no sentido de que um quadrado é uma figura geométrica que tem quatro lados, ele não consegue admitir que se possa supor que poderia ter dois lados, o de dentro e o de fora, ou oito, sendo quatro por dentro e quatro por fora. Nietzsche dizia que se $1+1$ for um homem somado a uma mulher o resultado pode ser 4 ou 5 . O pensamento "exato" não quer dar espaço à imaginação criativa, que é exatamente o que se precisa para entender e fazer arte. Como as "ciências exatas" são tomadas como modelo de pensamento, há mesmo em áreas de humanas como Direito e Arquitetura uma tendência ao robotizado.

Há um autoritarismo inerente ao pressuposto $A=A$. Não se pergunta porque se pode supor que haja $A$ como ente unitário e que ele possa ser = A. Hegel disse que não se pensa assim: um navio é um navio. Assim não se desenvolve o pensamento. $A=$ A quer dizer que cada ente tem a sua entidade, mas também que ele não muda sua identidade, que ele é sempre idêntico a si mesmo. O que se passa na empiria é mais complexo do que isso. Eu acho que sou eu, tenho a 
identidade do meu nome, da minha carteira de identidade, mas o que esse "eu" irá se tornando ao longo da vida, a ponto de se desfazer. Pressupomos uma identidade quando falamos de uma obra de arte, achamos que ela sempre foi e será vista do mesmo modo, o que não é fato.

Não há nada que seja absoluto, nem mesmo essa assertiva. Querer, como Fichte, que a relação entre eu e não-eu seja o absoluto é achar que o não-eu enquanto tal depende do eu. Isso só acontece dentro da lógica do eu. Ele não estava preparado para a teoria da evolução das espécies. Todo sujeito humano pode desaparecer, portanto pode e vai desaparecer a relação entre eu e não-eu.

Portanto, também a obra de arte não é $A=A$, como também o sujeito que a faz e a percebe não é livre de tendências contraditórias dentro de si. A obra não é seu conteúdo manifesto, porque o latente é o que mais importa. Há uma obra oculta na obra, encoberta por ela, que precisa ser descoberta como o potencial inconcluso da obra. Ela é a sombra de si mesma. Isso obriga a uma percepção mais acurada. A imaginação não apenas constitui a obra e fundamenta o pensamento, mas faz parte da percepção e reconstituição da obra pelo receptor. Ela é mais que dupla, ela tem diversos níveis de percepção, o que um nela enxerga não é o que o outro reconstitui.

Pascal dizia que a pessoa interessante enxerga várias pessoas bem interessantes pela vida afora. Se ela não tiver essa diferenciação em si, ela não vai perceber a diferenciação em outras. Se uma obra de arte for densa e complexa, as pessoas simplórias vão ter uma captação muito singela e não vão perceber o que vai além do seu horizonte tacanho de captação. Para elas, já são boas as obras medíocres. Também é possível fazer uma leitura crítica complexa de obras simples, simplórias. Daí vai parecer que o sujeito apenas desanca o pau, quando de fato ele gostaria de levar os leitores a perceber obras de melhor nível. Se eles não tiverem, porém, essa vivência densa e complexa e acurada de grandes obras, não vão perceber as obras simples em sua simploriedade. Assim como se aprende a ler uma obra de arte, aprende-se ao ler também a ler a realidade, o perfil das instituições, os atos do governo.

Em Kant, Deus não é apenas uma ideia da razão, mas a Santíssima Trindade mais a Virgem Maria são a estrutura mesma da mente pensante. É um modelo europeu, católico, de uma era anterior à "morte de Deus”. Ele é um modelo mecânico. Da primeira para a segunda edição da KrV a liberdade evapora. Tem-se um modelo para a "máquina administrativa do Estado de Direito", mas não há espaço propriamente para a arte, pois ela não tem lugar nas meras percepções, já que ela, uma percepção estruturada e significativa, não tem lugar no espaço do entendimento conceitual, ela também não se confunde com um juízo (nem mesmo do gosto), para ficar no teto, entre os quartos e o telhado: ela não teria inclusive espaço na razão, já que lá só as vivências do sublime poderiam repinicar nas ideias.

Se a arte não tem um lugar próprio, ela é um estorvo, ela não tem razão de ser. Se ela é para ser o exercício da ideia de liberdade, essa é uma ideia vazia, pois não se contrapõe a nada que seja uma coerção. 0 "Estado" aí não tem coerção nem exploração de mão de obra e nem classes; a "mente" não tem aí um "superego", uma instância repressiva interiorizada, mas ela também não tem instintos, pulsões, tensões afetivas, valores. Ela é apenas uma máquina de pensar, assim como o Estado é uma maquinaria administrativa.

Descartes, ao optar pelo modelo matemático (antes aritmético) de verdade, além de pressupor que tudo seria redutível ao numérico, como se este esgotasse o real, retomou o modelo grego de verdade como "homoiesis": $2+2=4$. Sob a aparência de uma revolução científica moderna, manteve-se dentro da tradição: $X=Y$. Seja supondo que há um mundo das ideias que é copiado para a realidade, seja uma realidade que se reflete no mundo ideativo, o que se tem é uma equivalência, uma equiparação. Kant rompeu com isso ao dizer que a imagem que temos na mente do fenômeno das coisas não é a própria coisa, portanto $A \neq A^{\prime}$. Ele não examinou o que significaria isso para a revisão do conceito de verdade, achou que podia continuar com a antiga "coincidência" entre coisa e concepção mental. Por natureza, o que está na mente é diferente das coisas.

Heidegger propôs um retorno mais radical aos gregos com o conceito de "alétheia", em que a coisa vai se desencobrindo para o sujeito existencial: ela se revela, desvela e novamente vela. No chamado Heidegger II ${ }^{11}$ do Vom Ereignis (Do acontecimento), ele procura nuançar isso: quando algo se desencobre, está ao mesmo tempo encobrindo outros aspectos, o ver pode ser um modo de não ver, todo mostrar-se é um esconder. Mesmo que a "coisa" fique negaceando para lá e para cá, mostrando para esconder, escondendo para mostrar, o que está subjacente ainda é a concepção de "homoiesis", de uma equivalência entre o que está na mente e o que a coisa seja. Mesmo que 
se diga que o sujeito deve ter a liberdade interior para receber os diversos aspectos do objeto e que a coisa deve ter a liberdade de se mostrar como ela é, não se altera a busca de uma coincidência entre o que está na mente e o que seja a realidade.

Há diferenças, contudo: 1) não se quer confundir a verdade com a redução dela à correção conforme paradigmas, pois estes não conseguem apreender a complexidade dinâmica do real; 2) não se pode reduzir a verdade a algo fixo, imutável, até mesmo eterno, cujo modelo seria matemático; 3) não se quer reduzir a realidade ao quantitativo, pois este não a abrange; 4) o "matemata" deve ser entendido como aquilo que se pode aprender e transmitir de algo, o que se pode "contar" a respeito, e não apenas contabilizar; 5) devese abranger o máximo de aspectos relevantes do objeto, não os escondendo sob uma profusão de detalhes supérfluos; 6) não existe uma alma eterna como fundamento do eu e do conhecimento, pois o ser humano é um finito, que acaba com a morte; 7) o eu cognoscente está em relações mutáveis e mutantes, que alteram não só as circunstâncias, mas até a ele mesmo; 8) o eu não se confunde com a dimensão consciente, pois esta é como uma espuma sobre o mar das pulsões inconscientes; 9) o tempo do conhecimento não é apenas uma sequência linear, sucessiva, e sim presença do passado e antecipação do futuro no presente; 10) o espaço cognitivo se dá do homem como um estar no mundo em companhia de outros humanos, portanto, não faz sentido falar em verdade revelada, como oriunda de uma fonte divina, seja Apolo, Jeová ou o Espírito Santo; 11) o belo não é mais a expressão sensível do correto, conforme foi ao longo de sua história controlada pelo poder; 12) o belo é um exercício da liberdade criativa necessária para se buscar o verdadeiro; 13) a arte como repositório do belo precisa fazer parte da formação dos jovens para eles poderem se tornar cidadãos conscientes; 14) a arte é um refúgio da mente em tempos de opressão e permite sugerir o que de outros modos não se pode dizer; 15) a arte torna a vida mais suportável e melhor, inclusive de um povo todo. 
